À l'intersection des discours de spécialité :

hétérogénéité et unité

\title{
From non-specialised to specialised: Civilisation in Langues Étrangères Appliquées. The topic of homeownership and the property market in the United Kingdom
}

\section{Pauline Tee Anderson}

\section{OpenEdition}

\section{Journals}

\section{Electronic version}

URL: http://journals.openedition.org/asp/1834

DOI: $10.4000 /$ asp. 1834

ISBN: 978-2-8218-0414-2

ISSN: 2108-6354

Publisher

Groupe d'étude et de recherche en anglais de spécialité

\section{Printed version}

Date of publication: 30 November 2010

Number of pages: 87-103

ISSN: 1246-8185

\section{Electronic reference}

Pauline Tee Anderson, «From non-specialised to specialised: Civilisation in Langues Étrangères Appliquées. The topic of homeownership and the property market in the United Kingdom », ASp [Online], 58 | 2010, Online since 30 November 2013, connection on 02 November 2020. URL : http:// journals.openedition.org/asp/1834; DOI : https://doi.org/10.4000/asp.1834

This text was automatically generated on 2 November 2020 .

Tous droits réservés 


\title{
From non-specialised to specialised: Civilisation in Langues Étrangères Appliquées. The topic of homeownership and the property market in the United Kingdom
}

\author{
Pauline Tee Anderson
}

\section{Introduction}

1 The focus of the last three conferences organised by the GERAS ${ }^{1}$ and in particular the theme of the 2009 conference - "From non-specialised to specialised: routes towards specialised English" - provides an opportunity to consider the position on the nonspecialised-specialised continuum of Langues Étrangères Appliquées (LEA) and its course components, in this case civilisation. Should this be left in its traditional position at the non-specialised pole of the continuum, or can it be adapted to the various specialities of different LEA courses and therefore be placed at, or towards, the specialised pole? In attempting to answer these questions, it is essential to consider the teaching and learning context of LEA which, logically, will have an effect on the content and methods chosen for the civilisation courses designed for the students concerned.

2 The topic of homeownership and the property market in the United Kingdom will be used as an example of the approach suggested here. This is part of the British Civilisation course followed by third-year students of Langues Étrangères Appliquées aux Affaires et au Commerce at the University of Perpignan. These are clearly important issues since house prices and mortgage rates are constantly in the news and the former are used to measure the state of the UK economy. Moreover, the British are often described as being "obsessed" with homeownership. 
3 The fact that different aspects of the topic are depicted in cartoons in the British press is a further indication of its bearing on people's lives. The use of these documents as teaching aids will be discussed. Glaser (1980) has demonstrated how they trace the evolution of British society, making them useful additions to civilisation courses; the examples selected here (see Appendix) show how certain events have been repeated, since some of the documents dating from the early 1990s are pertinent today. As Smith (2008) notes, "the newspaper cartoon, often described as the most perishable of art forms, gets a new lease of life when what goes around comes around".

\section{Langues Étrangères Appliquées on the non- specialised-specialised continuum}

\subsection{The teaching and learning context}

4 To understand the position of LEA in the French university system - and its place on the above-mentioned continuum - it is useful to look at its origins. These can be traced back to 1970, when two members of Parisian universities set up courses consisting of languages, law and economics (Perreau 1990: 84) as an alternative to those offered by traditional language departments. ${ }^{2}$ The idea quickly gained momentum and paved the way for the official recognition of LEA by the Ministry of Education in 1973. Although the impetus behind this movement has some negative aspects (Tee Anderson 1999: 24; Crosnier 2002: 158), it is important to remember that the pioneers of these new vocational courses were convinced that sectors like business and tourism needed staff with good modern language skills. There was thus a clear aim to move from a nonspecialised to a specialised language approach at a time when English for Specific Purposes (ESP) was in its infancy.

5 However, almost four decades later, and despite its success in terms of student numbers (Narcy-Combes 2008a: 133) and the emergence of doctoral research in LEA (Gallet-Blanchard 2008), its hybrid nature is still criticised by some. Indeed, LEA courses lie somewhere between those of academic language departments and the highly specialised vocational courses offered, for example, by Instituts Universitaires de Technologie (IUT), whose language components have been greatly influenced by the theory and practice of Languages for Specific Purposes (LSP). The facts that "LEA/ LANSAD Convergences/Divergences" 3 was the theme of a symposium held at the University of Nantes in January 2006, and that a special issue of Les Cahiers de l'APLIUT ${ }^{4}$ was subsequently devoted to this question, ${ }^{5}$ clearly indicate the importance of, and the interest in, the positioning of LEA and the practical implications that this can have. LEA students - who study two (or sometimes three) modern languages at the same level are not "specialists" in English, German, Italian, Spanish, etc., this term being reserved for their counterparts in LLCE departments. ${ }^{6}$ And they are not "non specialists" either, as LANSAD students used to be called. This newer term is no better suited to LEA students since they are not specialists of the fields to which their courses are geared, for example business and commerce (Tee Anderson 1999: 38). As Narcy-Combes underlines, they are not in fact specialised in languages, civilisation, translation or the technical subjects making up their courses, although they are taught by specialists of these fields (2008b), a state of affairs that is unlikely to change in the near future in view of the difficulty of recruiting teaching staff specialised in LEA (Narcy-Combes 
2008a: 132). This last point is crucial in that it largely explains why these courses have never fully broken away from the conventional, non-specialised approach of academic language departments: not only do traditional subjects like civilisation still feature prominently on many LEA curricula but, in some cases, they continue to be taught in the time-honoured way.

6 As for LEA students, their fundamental characteristic is that their academic backgrounds, motivations and future plans are very diverse. ${ }^{7}$ Many are attracted to LEA because they like languages (which - it should be noted - does not necessarily imply a taste for LSP), whereas some choose this course because they have a more technical background and wish to continue their commercial studies, for example, while improving their language skills. Other reasons include the wide range of subjects (and therefore career options), the practical nature of the course and the fact that it is a good preparation for more specialised courses for which a degree, for example, is an entry requirement (Tee Anderson 1999: 49). The question of LEA students' career goals is a thorny one since, despite the vocational nature of the course they have chosen, these tend to be relatively open or even non-existent (Crosnier 2008: 23, 30). This situation is not very helpful when it comes to course design; however, it is important for the teacher to be aware of these different tendencies and to try to take them into account.

7 The route towards specialisation is clearly long. In many universities, LEA courses up to bachelor's degree level ${ }^{8}$ consist of general English with an economic and legal flavour (Crosnier 2008: 23, 30) and are therefore reminiscent of the first courses mentioned above. In others there is an earlier move towards specialisation: students at the University of Perpignan, for instance, begin increasingly specialised Business English classes in the second year of their bachelor's degree. Yet progress towards the acquisition of specialised language is still slow compared to that possible in LANSAD classes, where students' knowledge of their field of study advances much more quickly than that of LEA students. Since it would be absurd for the latter to learn specialised language in a vacuum, this question is closely linked to language teachers' ability and willingness to find ways to compensate for their students' lack of knowledge of certain specialised areas despite the fact that, in theory, their role is to teach language and not subject matter. ${ }^{9}$

\subsection{Civilisation: topics and teaching materials}

8 In any civilisation course, it is clearly essential to cover the fundamental aspects of the nation concerned and therefore topics situated at the non-specialised pole of the nonspecialised-specialised continuum. These are as relevant to LEA students as they are to LLCE students since, whatever their future career, knowledge of the cultures of the countries whose languages they speak is essential (Gallet-Blanchard 2008: 17). There is a further question to consider. Whereas LEA students whose interests lie more in languages than in business (for example) are likely to find general topics motivating, those who have clear career goals directly linked to their course may feel that some of their classes - for instance civilisation - are too general to help them achieve these. Is it feasible to cater for both groups? Van der Yeught (2008: 56-57) has demonstrated that it is possible to develop "applied civilisation" courses which are situated towards the specialised pole of the continuum but which cover essential non-specialised areas of this subject; his fourth-year LEA course entitled "Wall Street and the Making of 
America: 1792-2000" links the study of New York's stock exchange and financial quarter - and their language - to the key historical, economic and social events that have helped shape the country. The topic of homeownership and the property market in the United Kingdom is in a similar position on the continuum.

Less traditional teaching materials can be incorporated into civilisation as into other courses. Van der Yeught uses films showing the culture and language of Wall Street to enrich his classes, thereby applying FASP methodology. ${ }^{10}$ It will be seen how cartoons can be used to illustrate and develop certain aspects of the topic selected despite the difficulty of some documents. Pothier (1994: 88) identifies the range of knowledge and skills needed to understand and appreciate topical cartoons of the type used here: an awareness of current affairs, the ability to make sense of verbal humour and symbolic representations, and also cultural competence. It is clear that most of those given as examples in this article would be incomprehensible to students if they were not already familiar with certain specialised knowledge and vocabulary. Showing them too early in the learning process would therefore be more likely to lead to confusion - and even to a sense of failure - than to the enjoyment aimed at. Whereas it is possible to use cartoons based on unknown information to guide learners through target knowledge, it seems more fruitful to use documents containing several difficulties to reinforce and discuss points already studied. This approach can give learners the pleasure and sense of achievement resulting from understanding the joke, thus providing "experiences of success" which may have a positive effect on motivation (Dörnyei 2001 in Guilloteaux \& Dörnyei 2008: 58). It also has some chance of producing smiles and laughter, a very important point since it has been established that a humorous atmosphere encourages divergent thinking (Ziv 1983: 68-69) and creativity (Ziv \& Ziv 2002), which can generate a range of interesting - and amusing - interpretations of the situations shown as well as student-induced laughter, and therefore further success. Such discussions represent a change of activity and pace in a civilisation class, in which the transmission of information by the teacher often predominates. The playful climate produced by cartoons and students' comments on them should also contribute to the creation of a motivating classroom environment which can have an impact on learning achievement in the longer term (Dörnyei 2007: 719). Moreover, Ziv (1988) has shown experimentally that using humorous teaching material which is prepared in advance and which is directly linked to target knowledge promotes learning.

\section{Homeownership and the property market in the United Kingdom}

It is tempting to make a broad division here: whereas most aspects of homeownership concern the non-specialised pole of the non-specialised-specialised continuum, many aspects of the property market concern the specialised pole. However, it is in fact extremely difficult to separate the two and, indeed, this analysis will reveal the intertwining of the political, cultural, economic and social factors at play, highlighting questions of behaviour and attitudes (non-specialised) as well as specialised information and terms. Examples of the use of cartoons and students' reactions to them will also be considered.

11 The importance of property ownership is not new. Until the Great Reform Act of 1832, which extended the franchise in Britain, only men who owned property valued for land 
tax at more than forty shillings a year had had the right to vote; despite further Reform Acts, only male householders were able to vote throughout the $19^{\text {th }}$ century. It was in this context that one of the building societies of the time publicised its aim to enable young men to acquire property so that they would enjoy this right (Paxman 2007: 122). A different political focus has been put on the issue in more recent years. As any LLCE or LEA student of British civilisation will know, a key aspect of Thatcherism was the importance of the individual and the reduction in the role of the State: people were thus encouraged to take responsibility for their lives. In terms of homeownership, this translated into Mrs Thatcher's pledge to turn the country into a property-owning democracy; Conservative governments between 1979 and 1997 therefore promoted homeownership for all (for example through tax incentives and the Right-to-Buy scheme, which enabled tenants to purchase their council houses or flats at well below their market value), a policy which was continued by New Labour. It is interesting that during one of the three leadership debates that took place shortly before the General Election of 6 May 2010, Gordon Brown ${ }^{11}$ echoed Margaret Thatcher's undertaking when he underlined his party's intention to create a majority owner-occupancy democracy. ${ }^{12}$ This "peculiarly British assumption" that everyone wants to own their own home, and that everything should be done to help them to do so, can be seen as "almost defining modern Britishness" (Roe 2005).

Another ingredient of Britishness is the need for and respect of privacy. As Paxman explains,

A truly comparable word for "privacy" simply does not exist in French or Italian, yet in England it is one of the country's informing principles. [...] The importance of privacy informs the entire organization of the country, from the assumptions on which laws are based, to the buildings in which the English live. (2007: 118)

Indeed, the "desire for privacy" requires an explanation in French, for example (désir de se cacher aux regards indiscrets, de se tenir à l'écart de la société13) and is not always understood by people from cultures that do not attach such importance to it; in these cases, certain behaviours - seen by the English as manifestations of their discretion or wish not to intrude - may be interpreted as indifference, disdain or superiority (Paxman 2007: 116, 118, 129). The "right to privacy" ${ }^{14}$ and also "the privacy of one's own home" are sacrosanct, with houses being considered more private than flats. As Fox puts it (2005: 111), "the English all want to live in their private little box with their own private little green bit"; both authors stress the importance of having a back garden which can be enjoyed in private. Fox goes on to mention other cultural issues:

But an Englishman's home is much more than just his castle, the embodiment of his privacy rules, it is also his identity, his main status-indicator and his prime obsession. And the same goes for English women. (2005: 113)

A German architect who studied the English house in the early 1900s recognised this, concluding that "no nation is more committed to its development, because no nation has identified more with the house" (Muthesius 1979: xv in Paxman 2007: 119). This emotional attachment is illustrated by the fact that many people in the UK give their house a name, the importance of which is discussed in a popular novel:

Podmore's Thatch. Olivia thought it a ridiculous name, and she felt embarrassed every time she had to say it; she had even suggested that Penelope think up some other name for the old place. But Penelope knew that you couldn't change the name of a house any more than you could change the name of a person. (Pilcher 2001: $143)^{15}$ 
The names of houses and the names of human beings are thus put on an equal footing. Moreover, the mentality discussed by these authors is exploited by a series of television advertisements shown in 2010: "At British Gas we know that your home is your world".

The question of status mentioned by Fox is a critical one. This is reflected in the very fact of homeownership (owner occupiers enjoy higher social status than people living in rented accommodation), as well as in the type of property owned. While it is important to stress the pleasure of purchasing one's first home, with the sense of security ${ }^{16}$ and achievement that it brings, in recent years the "Home Sweet Home" aspect of ownership has tended to be eclipsed by the importance of monetary value and investment. This can be linked to the fact that Britain is a masculine society: ${ }^{17}$ in this type of culture, money and material possessions are important and success is essential; the latter is to be admired and is rewarded by wealth and social status (Bollinger \& Hofstede 1987: 149, 152); recognition and advancement are also vital (Hofstede \& Hofstede 2005: 132). As far as housing is concerned, the property ladder is the main manifestation of these attitudes. First-time buyers usually begin on the bottom rung for example by buying starter homes which are built with this sector of the market in mind - and will later buy something bigger, better (a house rather than a flat, a detached rather than a semi-detached or a terraced house, etc.) and/or in a more desirable location. ${ }^{18}$ Climbing the property ladder is a clear sign of increased affluence and status, both being essential in this money-oriented and class-conscious society. Another important point is that the majority of owner occupiers in the UK keep track of the value of their home and do what they can to maintain it, and will not make certain improvements - such as building an extension or a conservatory - if they cannot recover their investment should they decide to sell. This is because each type of house in each street has a ceiling price at any one time, depending on the market; most people will forgo the pleasure of being more comfortable in their home rather than "overspend" on a particular type of property.

17 As mentioned above, it is possible to use cartoons to encourage discussion and therefore learner involvement. It is not difficult for students to draw a parallel between the situation in cartoon 1 and the mentality of many British home buyers. Documents which show animals imitating humans usually produce immediate smiles and laughter among students and, in this case, the choice of protagonists heightens the absurdity of the need to acquire a bigger and better home as soon as circumstances appear to be favourable. Just like the snail that has purchased an oversized and rather unsuitable tortoise shell, people are prepared to overstretch themselves financially and take risks in order to upgrade their homes, even when this is not strictly necessary. The snail is taking advantage of lower interest rates but, of course, these can rise again at any time; students tend not to feel any sympathy for the snail's possible repayment difficulties, but some see it as a potential victim of the social pressures of the culture it lives in. Although it seems unlikely that many people made this type of decision during 1992, when the cartoon was published and when the country was in recession, it should be noted that the British belong to a culture with low uncertainty avoidance, meaning that they tend to take personal risks and hope for success, whereas members of high uncertainty avoidance cultures (France, for example), take fewer personal risks and fear failure (Bollinger \& Hofstede 1987: 110). ${ }^{19}$

18 The specialised points that will now be outlined, which involve the economy and the mortgage market, are more relevant and accessible to LEA students - who can be asked 
to research facts and figures - than to LLCE students. The expression "as safe as houses", which can be applied to investments of all kinds, reflects the fundamental belief that buying property does not involve any risk. However, the longstanding "boom and bust" pattern of the UK economy has twice been mirrored dramatically in the property market, the first time in the late 1980s and early 1990s. ${ }^{20}$ The collapse of property prices and its terrible effects on people's lives came as a great shock to British people; those who had to sell their homes for less than they had paid for them had to overcome "a huge psychological hurdle" (Tatch 2009: 9). Crucially, the Conservative governments of this time pursued a policy of high interest rates and mortgage borrowers in the UK are at the mercy of interest rate fluctuations (hence the importance given to these in the news). As the recession of the early 1990s took hold, repossessions by lenders soared ${ }^{21}$ and the property crash gave rise to a new phenomenon and term: negative equity, which indicates that the mortgage on a property is higher than its market value. Until the economy - and with it property prices - began to recover in the second half of the 1990s, people whose homes were in negative equity and who could not meet their mortgage payments either sold their property and were left with a substantial debt or, as the situation worsened, simply handed in their keys to their mortgage lenders who did not necessarily make serious attempts to recover the shortfall when there was little or no hope of doing so;22 banks and building societies therefore absorbed some of the losses of the crash. Many owner occupiers who were able to meet their mortgage payments were trapped in unsuitable starter homes, in some cases unable to have a family (or more children) because of cramped living conditions; others were obliged to continue to share a home with partners from whom they wished to separate. Again, learners can easily understand that cartoon 2 is a light-hearted illustration of the very serious human and social consequences of what began as political and economic issues. The cartoonist's use of the term "negative equity trap" shows that it had passed into general usage.

Cartoon 3 refers to another dramatic situation: the repossession of a family home. It presents more of a challenge to students than the previous two documents and is a prime example of the knowledge and skills they need to decipher some cartoons; they also have to disentangle fact from fiction. One of the difficulties, the play on words based on "detached house", shows a potential pitfall of using these documents and other forms of humour with language learners: they are sometimes presented with distorted utterances ("We detached it from its owner"). However, this can be turned into a learning opportunity since students can be asked to provide an acceptable way of expressing the idea, for instance "We repossessed it". And is it only the language which is deformed? Do mortgage providers actually take buyers to visit properties? Before the crash under discussion, this would have been unthinkable. However, in view of the numbers of people handing in keys to their lenders, some of their staff took on tasks for which estate agents are normally responsible. Was the cartoonist thinking of this point when he drew the cartoon? This is not necessarily the case. Although it would have been possible to show an estate agent ("The building society detached it from its owner"), the haughty expression of the building society employee - and his apparent disdain for the previous owners of the house, and perhaps even his pride in the tough stance taken by his employer - make the cartoon more of an attack against mortgage lenders who, at the time, were much maligned for their unsympathetic treatment of homeowners in difficulty. And as one student commented, his words may contain a veiled warning to the potential buyers: "Pay or else!" Another student drew attention 
to an interesting point: the property looks like a semi-detached or end-of-terrace house although it is described on a sign as a detached house. Learners see this sales ploy as rather pointless until they realise that the description would be more likely to arouse British buyers' interest: not only is a detached house further up the property ladder, but it also gives its occupants increased privacy. What type of house is it in fact? As is often the case with cartoons, there is no "right" answer and the situation is therefore open to interpretation; this is one of the advantages of using these documents as teaching aids.

Students learning of these events would probably think that buyers and lenders would not repeat their mistakes. But such is British people's obsession with property that their memories are short. During the first years of the new millennium, the explosion of house prices - which peaked in 2007 - was stimulated by several new factors such as low interest rates and increased competition in the mortgage market, the deregulation of the mortgage industry in $\mathbf{1 9 8 0}$ having made it possible for banks - and not only for building societies - to provide mortgages. The freedom traditionally enjoyed by banks in the UK reached a new level and led to highly irresponsible lending practices. For example, just months before it was saved by the Government in the autumn of 2007, Northern Rock was advertising loans of up to $125 \%$ of the value of the home being purchased. ${ }^{23}$ Another new factor is that this boom was fuelled by television, property programmes having accounted for a substantial proportion of reality shows for about the last ten years. Channel 4 is particularly known for its copious output of what has been dubbed "property porn"; one of its most popular programmes, Property Ladder, shows viewers "how to win the property game" by buying and renovating properties either to sell or to let. On this and numerous other such shows, many amateur property developers are seen making tens of thousands of pounds for a few months' work. They therefore appeal to people's greed, a character trait which became acceptable during the Thatcher years.

21 It is not just property programmes that compare the property market to a game: visitors to The Market Oracle website who click on the "Housing Markets" link will see an illustration showing the corner of a Monopoly board complete with house. Moreover, cartoon 4 depicts a family playing Monopoly and refers to buy-to-let mortgages, the introduction of which contributed to the boom - and, partly, to the appearance of amateur property developers - since they encouraged ordinary people to buy properties purely as investments and not as homes. But why does the player look dismayed on realising that he has bought or is about to buy such a property? Most people would be delighted to be in such a position. Perhaps he knows that lenders consider buy-to-let mortgages to be relatively risky and that they are therefore subject to higher interest rates although, in fact, mortgage arrears and repossessions in this sector have been low during the current recession (Ball 2010: 103). Or perhaps he is against the very existence of buy-to-let landlords who, like amateur developers, have had a profound effect on the UK property market.

Indeed, these two new types of property purchasers increased demand and therefore played a part in spiralling house prices, ${ }^{24}$ forcing many traditional first-time buyers out of the market. The apparent resignation of the couple depicted in cartoon 5 was not shared by all. In many cases, the British obsession with property acquisition became a frenzy, with young couples - for instance - borrowing astronomical sums ${ }^{25}$ which they could not afford but which mortgage providers were prepared to lend; the world at 
large was soon to learn the meaning of the hitherto highly specialised term "subprime". Such was their desperation to get onto the property ladder at this time that more than $10 \%$ of first time buyers were purchasing property with friends; in response, some firms built specially-designed "duet apartments" so that single people who could not afford to buy a property on their own could "enjoy the type of lifestyle that young professionals expect" (Quinn 2007). But history repeated itself when the country went into recession in 2008 and the property bubble burst, causing similar problems to those of the 1990s and inspiring cartoons 6 and 7 which, like several of the others, could refer to either property crash. However, a new factor affecting both the property market and business in general - the credit crunch - is referred to in cartoon 8. The banks, having largely caused the bubble by lending too easily, contributed to the crash and continuing slump by refusing to lend both to businesses (resulting in increased unemployment) and to would-be home buyers eager to take advantage of lower property prices. Ball (2010: 105) refers to the decline in mortgage lending as "dramatic and unprecedented": whereas 60,000 mortgages were being granted per month during the summer of 2007 , the number had fallen to 18,000 in November 2008, when the cartoon was published.

The activities of many amateur property developers - some of whom gave up well-paid, secure jobs to devote themselves to their new careers - have obviously come to an abrupt halt. Ever inventive, Channel 4 has brought out a new programme whose title emphasises the "game" analogy: Property Snakes and Ladders, ${ }^{26}$ which features amateur developers who bought at the height of the market and who therefore find themselves in very difficult positions. The property game has thus become more sinister but cable and satellite television channels continue to repeat the shows that have done so much damage, with a warning at the foot of the screen: "Prices correct at time of production". Viewers are thus still being influenced by these programmes, and their jargon - and the ethos behind it - continues to be reinforced. Many of those who catch the "property bug" seek to create an atmosphere of "aspirational living" to make their property desirable. They often target "young professionals", "urban, cool young professionals" or the "urban professional market", these being seen as the most lucrative buyers and tenants. "Open-plan living" is the order of the day, with rooms becoming "spaces" and roof terraces and gardens "outside spaces". The "wow factor" and "cutting-edge design" are essential if the best possible price is to be "achieved", this being more likely in an area known for its "café culture". "Up-and-coming areas" with the beginnings of a café culture and other signs that they are becoming fashionable are particularly sought after by property developers.

\section{Concluding remarks}

Van der Yeught (2008: 54-55) proposes two requirements which determine whether a specialised field can be considered to include civilisation: a) the specialised field and its language must not be universal but characteristic of the nation under consideration, since a nation's civilisation emanates from its history, and b) the speciality concerned and its language must go far beyond its professional community and make a significant contribution to the experience of the nation. Although the United States and other English-speaking countries may share certain aspects of the UK property market as well as British people's attitudes to homeownership, and some of these have been 
"exported" to other countries, this topic can clearly give learners a window into Britishness as well as an understanding of recent history and its effects on current events. It is therefore considered that these two requirements are fulfilled.

A third requirement for "applied civilisation" is put forward by this author: the topic chosen to give access to a country's civilisation must correspond to the field of application of the LEA course concerned (Van der Yeught 2008: 55). Again, this is the case. The sale and purchase of real estate is clearly part of the business world and, in view of the number of UK and other foreign buyers of properties in France, this is one of the sectors that offer career opportunities to LEA graduates. Moreover, it is felt that the topic proposed has a practical application; for example, when dealing with British house hunters, students would know the importance of stressing the privacy of a garden or roof terrace, the desirability of a certain location, the investment potential and so on. They would also be more likely to understand - and reply appropriately to questions like "Would it be worth adding a room in the loft?" and "Will it be easy to sell?"; in the latter case, they would not be surprised that potential purchasers are thinking about the sale of a property before they have even bought it. This practical aspect could be reinforced if the course were linked to a Business English class for which it would be possible to organise activities that do not seem appropriate for a civilisation class. These could include meetings and presentations about how to market certain properties, and role plays between estate agents and buyers or sellers. As preparation, it would be useful to show excerpts from programmes that give tips on how to present a property for sale and how to show it to visitors. It is true that, in view of the current recession and the weakness of the pound, this is not the best time to target British buyers; however, their obsession is such that the UK property market is gradually recovering and, in time, they will reappear as potential buyers of property in France and elsewhere.

It is for all these reasons that including civilisation in the routes to specialisation can be beneficial in the context in question and merits further exploration. As LEA students lie somewhere between the two poles of the non-specialised-specialised continuum, it seems appropriate that some of their course components should be in a similar position.

\section{BIBLIOGRAPHY}

Ball, Michael. 2010. 2010 European Housing Review. Royal Institute of Chartered Surveyors.

Bollinger, Daniel \& Geert Hofstede. 1987. Les différences culturelles dans le management. Paris: Les Éditions d'Organisation.

Crosnier, Elisabeth. 2002. "De la contradiction dans la formation en anglais Langue Étrangère Appliquée (LEA)”. ASp 35-36, 157-166.

Crosnier, Elisabeth. 2008. “LEA/LANSAD : Convergences/Divergences”. Cahiers de l'APLIUT 27/1, 18-31. 
Department for Communities and Local Government. 2010. "Housing market: mix-adjusted house prices, by new/other dwellings, type of buyer and region, United Kingdom, from 1993”. Table 507, updated February 2010.

Dörnyei, Zoltan. 2007. “Creating a motivating classroom environment”. In Cummings, Jim \& Chris Davison (eds.), International Handbook of English Language Teaching. Vol. 2. New York: Springer, 719-731.

Fox, Kate. 2005. Watching the English The Hidden Rules of English Behaviour. London: Hodder. (First published by Hodder and Stoughton 2004.)

Gallet-Blanchard, Liliane. 2008. "La place de la recherche et de la reconnaissance institutionnelle en LEA/LANSAD”. Les Cahiers de l'APLIUT 27/1, 10-17.

Glaser, Rosette. 1980. "Le dessin d'humour dans la presse populaire quotidienne britannique de 1945 à 1970 : Impressions et expressions de l'évolution d'une civilisation". Thèse pour le doctorat d'État, Université Paris III.

Guilloteaux, Marie \& Zoltán Dörnyei. 2008. "Motivating language learners: A classroom-oriented investigation of the effects of motivational strategies on student motivation". TESOL Quarterly 42/1, 55-77.

Hofstede, Geert \& Gert Jan Hofstede. 2005. Cultures and Organizations. Software of the Mind. London: McGraw-Hill.

Muthesius, Hermann. 1979. The English House. London: Crosby Lockwood Staples. (Condensed translation of Das englische Haus. Berlin, 1904-1905).

Narcy-Combes, Marie-Françoise. 2008a. "L'anglais de spécialité en LEA : entre proximité et distance, un nouvel équilibre à construire". ASp 53-54, 129-140.

Narcy-Combes, Marie-Françoise. 2008b. “Avant-propos”. Cahiers de l'APLIUT 27/1, 9.

Paxman, Jeremy. 2007. The English. London: Penguin Books. (First published by Michael Joseph 1998.)

Perreau, Dominique. 1990. "Langues Étrangères Appliquées. Un succès à double tranchant". Avenirs, ONISEP 419-420, 84-87.

Pothier, Maguy. 1994. "Grandeur et servitude de l'utilisation du dessin de presse en classe de langue”. Études de linguistique appliquée 94, 87-98.

Quinn, Ben. 2007. "Friends united by homes with two mortgages". The Daily Telegraph July 12, 12.

RICS Economics. 2008. "Transactions to edge up but prices remain depressed". 2009 Housing Forecast December.

Roe, Nicholas. 2005. "Why are we so obsessed with ownership?". Telegraph Property September 3, 5 .

Smith, David. 2008. "Timeless appeal of the classic joke". The Observer, November $23<\mathrm{http}: / /$ www.guardian.co.uk>.

Tatch, James. 2009. "Homeowner housing equity through the downturn”. Housing Finance (Council of Mortgage Lenders) 1.

Tee Anderson, Pauline. 1999. “L'Intégration de dessins humoristiques dans la didactique de l'anglais des affaires et du commerce. Le cas d'un enseignement en Langues Étrangères Appliquées". Thèse de doctorat nouveau régime, Université Montpellier III. 
Tremlett, Giles. 2009. "End of the dream for British expats in Spain”. The Guardian, July 24 (http:// www.guardian.co.uk).

Van der Yeught, Michel. 2008. "La Langue de spécialité au service de la civilisation en LEA : 'Wall Street and the making of America (1792-2000)"'. Cahiers de l'APLIUT 27/1, 51-59.

Ziv, Avner. 1983. "The influence of humorous atmosphere on divergent thinking”. Contemporary Educational Psychology 8, 68-75.

Ziv, Avner. 1988. "Teaching and learning with humor: Experiment and replication”. Journal of Experimental Education 57, 5-15.

Ziv, Avner \& Noémie Ziv. 2002. Humour et créativité en éducation. Approche psychologique. Paris: Creaxion.

\section{APPENDIXES}

Cartoons from The Spectator courtesy and (C) Press Holdings Media Group

Cartoon 1. 9 May 1992

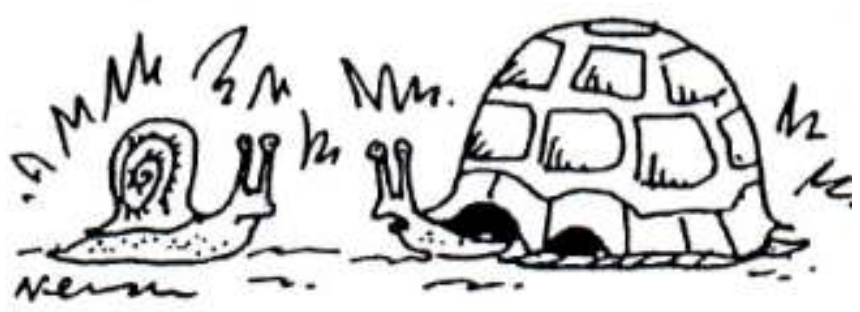

'Now interest rates have come down, I can afford somewhere bigger.'

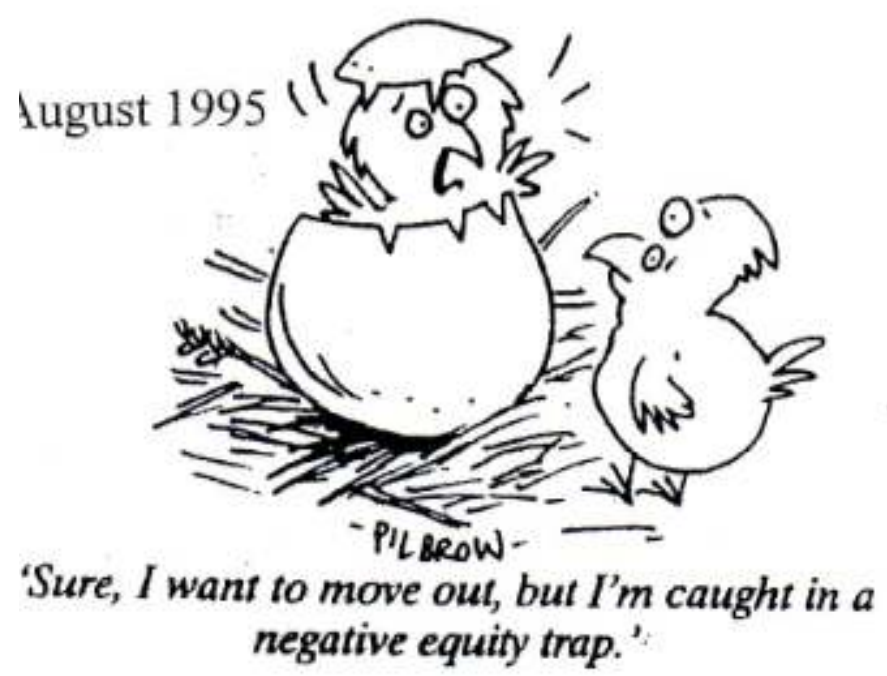

Cartoon 3. 5 August 1995 


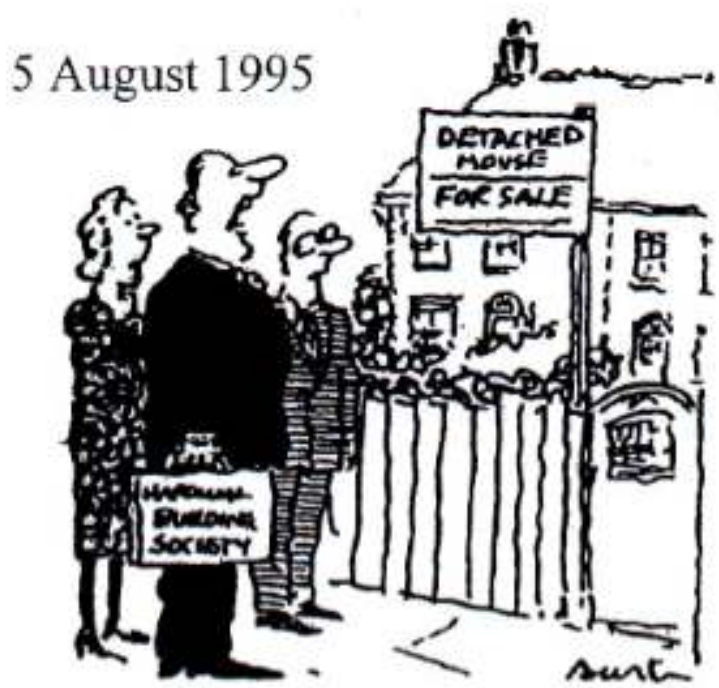

'We detached it from its owner.'

Cartoon 4. 20-27 December 2008

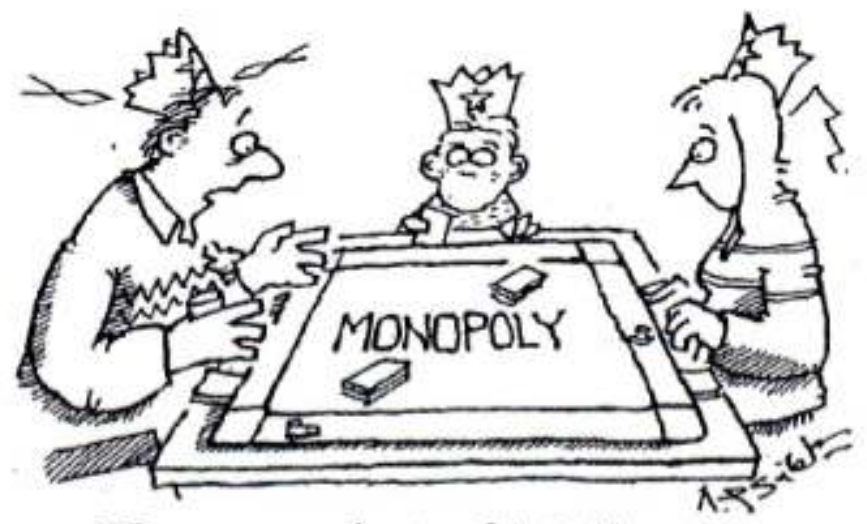

'Hang on a minute, this is "buy to let"!"

Cartoon 5. 7 February 2007

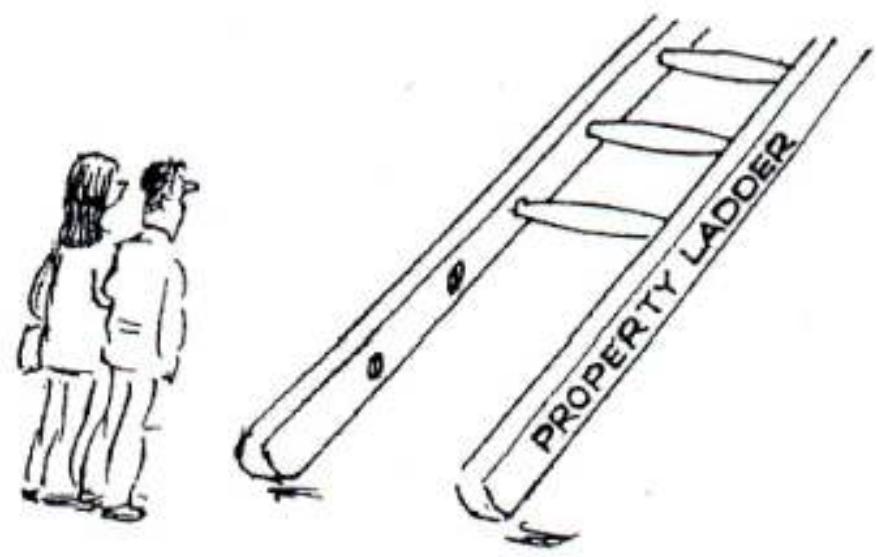


Cartoon 6. 22 November 2008

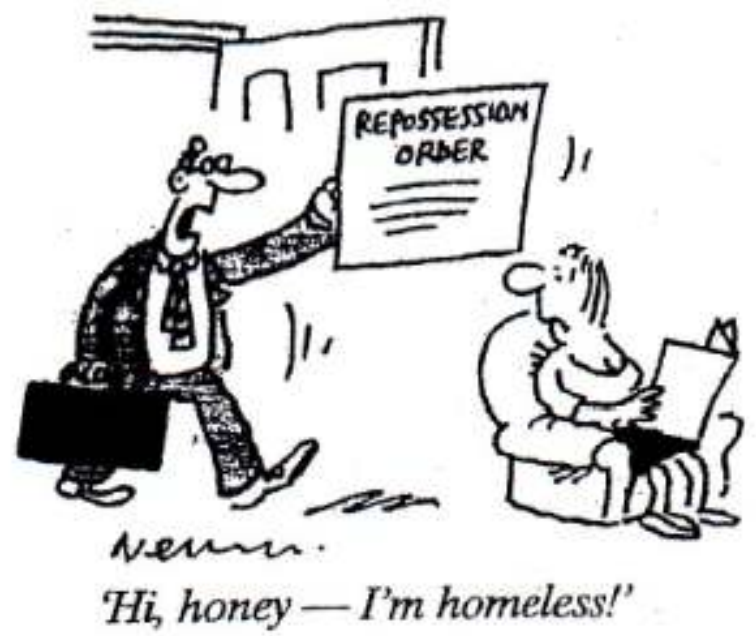

Cartoon 7. 8 November 2008

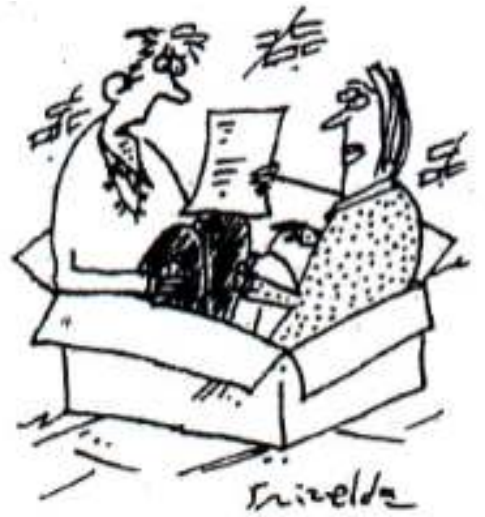

'Oh no! We're in negative equity!'

Cartoon 8. 29 November 2008

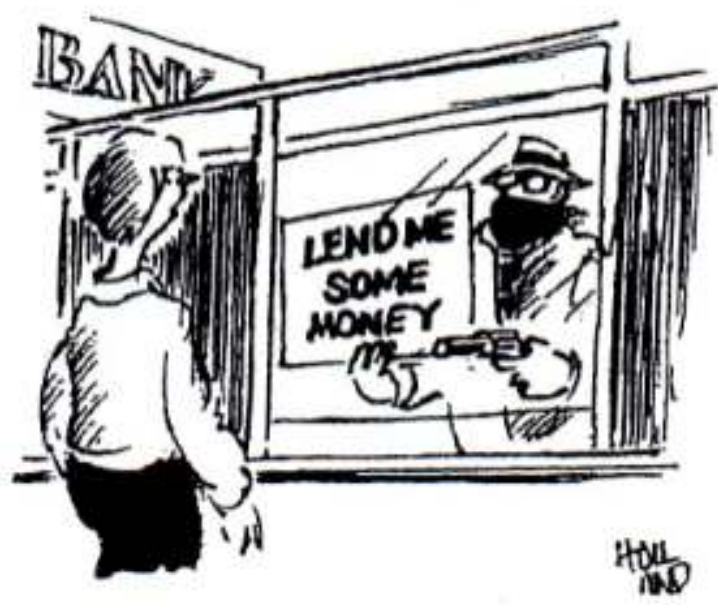

200000160000005400000054315 ECEA5.pctImage

$200000160000005400000054 C 5 B B F E D A . p c t$ 


\section{NOTES}

1. The $29^{\text {th }}, 30^{\text {th }}$ and $31^{\text {st }}$ conferences $(2008-2010)$ centred on the association's research on the multiplicity and unity of English for Specific Purposes.

2. These are now known as LLCE departments (Langue, littérature et civilisation étrangères). In this article they are also referred to as "academic language departments".

3. LANSAD: Langues pour Spécialistes d'Autres Disciplines

4. APLIUT: Association des Professeurs de Langues des Instituts Universitaires de Technologie

5. Volume $17, \mathrm{n}^{\circ} 1$, February 2008

6. This use of the terms "specialists" and "non specialists", which refer respectively to LLCE students and to those studying disciplines other than modern languages, is not to be confused with the question of specialised and non-specialised language and content which is the subject of this article.

7. Students' motivations and career plans are discussed during the first class of each academic year.

8. Licence

9. For an analysis of issues linked to LEA students' and teachers' knowledge of subject matter, see Tee Anderson (1999: 33-38); Crosnier (2008: 25-26) and Narcy-Combes (2008a: 131-132) discuss the pivotal question of teacher motivation.

10. Fiction à Substrat Professionnel (fiction set in a professional context)

11. The Prime Ministerial Debate, BBC 1,29 April 2010

12. It can be considered that both political parties have largely achieved their common aim since, between 1981 and 2006, the number of owner occupied dwellings increased by 50\% (Ball 2010: 102).

13. Harrap's New Standard French and English Dictionary (1996). Longman's Dictionary of Contemporary English (2005) defines "privacy" as 1. the state of being able to be alone, and not seen or heard by other people. 2. the state of being free from public attention.

14. Paxman (2007: 118) underlines the fact that this "right" is presumed and not enshrined in law.

15. Rosamunde Pilcher, [2000] 2001, The Shell Seekers. London: Coronet Books, Hodder \& Stroughton.

16. The question of security is important as leases in the private housing sector are often very short, for example six months. However, it will be seen that homeownership has given many people a false sense of security.

17. The degree of masculinity-femininity of a society is one of the four cultural dimensions that form the model devised by Geert Hofstede and his collaborators. On a scale of 0 (feminine mentality) to 100 (masculine mentality), Britain has a score of 66 and is in joint $9^{\text {th }}$ position out of 53 countries and regions; France, for example, has a score of 43 and is in joint $35^{\text {th }}$ position (Bollinger \& Hofstede 1987: 142).

18. Location is of utmost importance in UK property market terms, typical advice given by experts being: "Always buy the worst house in the best street" since such a property is considered to be a good investment.

19. Uncertainty avoidance can be defined as "the extent to which the members of a culture feel threatened by ambiguous or unknown situations" (Hofstede \& Hofstede 2005: 167). On a scale of 0 (low avoidance) to 120 (high avoidance), Britain has a score of 35 and is in joint $47^{\text {th }}$ position out of 53 countries and regions; France, for example, has a score of 86 and is in joint $10^{\text {th }}$ position (Bollinger \& Hofstede: 1987: 105).

20. During the downturn of the early 1990 s, house prices fell by $13 \%$ in the country as a whole and by $25 \%$ in many parts of the south of England (Tatch 2009: 1 ).

21. For example, 75,000 homes were repossessed in 1991 (RICS Economics 2008: 4). 
22. Some British homeowners in Spain, unable to meet their mortgage payments or sell their property, have recently repeated this behaviour and left their keys with their Spanish banks, who intend to pursue any debt (Tremlett 2009). This inappropriate practice has therefore been taken to other countries.

23. Northern Rock's advertisement shows cartoon characters and is entitled: "Our own place? Where's the money? IT'S YOURS with our together mortgages". These combined a secured mortgage and an unsecured loan (for instance, Mail on Sunday, 8 July 2007).

24. For example, these almost doubled between 2000 and 2007 (Department for Communities and Local Government: 2010).

25. At the height of the bubble in 2007, the average price for a home in the UK was $£ 213,807$ and the average price paid by first time buyers was $£ 163,161$ (Department for Communities and Local Government 2010).

26. Snakes and Ladders is similar to the Jeu de l'Oie; the ladders help players progress while the snakes represent a danger, obliging them to return to squares nearer the start.

\section{ABSTRACTS}

It is generally acknowledged that Langues Étrangères Appliquées (LEA) (Applied Languages) have a somewhat unique position in the French university system. This article first discusses these courses from the point of view of what can be called the non-specialist-specialist continuum, then examines the place of civilisation in LEA. Should this retain its traditional nature in all cases, or can it be one of the routes to specialisation for LEA students? An analysis of the topic proposed here - home ownership and the property market - demonstrates that it involves political, economic, social and cultural aspects of the United Kingdom, as well as current events. Whereas some of these would not be out of place in any British civilisation course, others are more suited to LEA students and, moreover, could have practical implications for them. The role of cartoons as teaching aids is also considered.

La spécificité des Langues Étrangères Appliquées (LEA) est largement reconnue. Cet article commence par la présentation de la filière sous l'angle de son degré de spécialisation et continue par l'étude de la place de la civilisation au sein de cette formation. Devrait-elle conserver son caractère traditionnel, quels que soient les destinataires de cet enseignement, ou constituer l'une des voies vers la spécialisation dans le cas des étudiants de LEA ? L'analyse du thème proposé - la propriété immobilière et le marché de l'immobilier - démontre qu'il comprend des aspects politiques, économiques, sociaux et culturels caractéristiques du Royaume-Uni, ainsi que des questions d'actualité. Alors que certains de ces points auraient leur place dans tout enseignement universitaire de civilisation britannique, d'autres conviennent davantage aux étudiants de LEA à qui ils peuvent, en outre, apporter des connaissances pratiques. Le rôle des dessins humoristiques comme supports pédagogiques est également traité 
INDEX

Mots-clés: anglais de spécialité, civilisation (britannique), dessin humoristique, LEA, propriété immobilière

Keywords: applied languages, civilisation (British), cartoon, English for Specific Purposes, homeownership

\section{AUTHOR}

\section{PAULINE TEE ANDERSON}

Pauline Tee Anderson is a Senior Lecturer in the Department of Applied Languages at the University of Perpignan. Her main research activities concern LSP, cartoons depicting the business world (language and culture, text and image, stereotypes) and their place in the teaching of Business English and civilisation. She is also interested in television advertising. anderson@univ-perp.fr 